https://doi.org/10.15407/socium2020.02.059

UDC: 316.332

Burak O.S., PhD. (Sociology), Senior Innovation Market Researcher, Edizon Innovation, FranzKollmann-Straße, 4, 3300, Amstetten, Austria, Master Student, Univertsity of Vienna, Institute for Sociology, Rooseveltplatz, 2, 1090, Vienna, Austria, email: Oksana.burak20@gmail.com, ORCID iD: https://orcid.org/0000-0003-0842-1646

\title{
(IN)EQUALITY OF OPPORTUNITY IN EDUCATION AND THE MECHANISM OF NON-REPRODUCTION
}

In this article we would like to discuss, based on the results of empirical studies, the question of monopoly position of educational institutions in the distribution of life chances and the factors that could promote social mobility. The main theoretical focus is on the theory of reproduction and on the new theoretical perspective of non-reproduction. Frequently it is precisely the education system itself, the one that inhibits upward social mobility and serves to preserve and reproduce the existing social order with its inequalities. A child's path throughout the school can be strongly influenced by its class of origin. This principle underlies the theory of reproduction. However, the theory shows its "blind spots", this is, when a child doesn't reproduce its own class and successes an upward transition from the lower class to the higher one. Chantal Jaquet names this process a non-reproduction and tries to work out a theory that could explain how a child can transform itself and avoids falling back into the behavior of its class of origin. From this point of view, some exceptional cases can serve as an excellent observatory to determine the decisive factors of an effective change. That is why we decided to look at a few life stories of "class crosses" in depth, using qualitative methods of analysis. The "class crossers" of our study were students from some middle schools (NMS) in Vienna, who could go to the grammar school (Gymnasium). Our aim was to empirically test some statements of the reproduction theory and of the new non-reproduction theory. For this purpose, we tried to reconstruct those factors, that could explain the success of the "class crossers". Five cases of transition were analyzed and, as a result, some institutional factors that make it difficult for young people to get to and through the gymnasium were identified. Besides, it was proved that adolescents must deal with them mostly on their own using the resources of the family and activating their personal set of mental and physical skills that Jaquet names "complexion". Moreover, some perspectives for further research opened up: the choice of profession that could lead to social upward mobility, the role of gender of the students and the educational level of their parents on the school path.

Keywords: social inequality, reproduction, non-reproduction, upward mobility, cultural capital, social origin, "class crosser", "complexion", educational transition, primary and secondary effects, habitus.

Бурак О.С., канд. соиіол. наук, старший дослідник ринку інновацій, Едісон Інновейшн, Франи Кольман Штрассе, 4, 3300, Амштеттен, Австрія, магістрант, Інститут соиіології Віденського університету, Рузвельт Плаи, 2, 1090, Відень, Австрія, етаil: Oksana.burak20@gmail.com,ORCID iD: https://orcid.org/0000-0003-0842-1646

\section{(НЕ)РІВНІСТЬ МОЖЛИВОСТЕЙ В ОСВІТІ ТА МЕХАНІЗМ НЕРЕПРОДУКЦІї}

У статті йдеться про монополію закладів освіти в сфері розподілу умов життя між членами суспільства та про фактори, які сприяють сочіальній мобільності. Теоретичний фокус зосереджений на теорії репродукиії та новій теоретичній перспективі “нерепродукиії". Досить часто сама система освіти блокує сочіальну мобільність, якій натомість мала б сприяти. Інститут освіти репродукує сочіальну систему і водночас присутню в ній сочіальну

(C) Burak O.S., 2020 
Burak O.S.

\begin{abstract}
нерівність. Освітній илях дитини може бути скерований ї̈ соиіальним походженням. Саме ия ідея лежить в основі теорї репродукиії. Проте і в ній є певні “прогалини”: коли дитина не репродукує клас свого сочіального походження, $і$ коли ій вдається зробити стрибок від нижчого соиіального класу до вищого. Шанталь Жаке називає иче явище “нерепродукиією” $i$ намагається пояснити, за яких умов відбувається цей перехід, зокрема через освіту. Саме тому глибинне вивчення окремих випадків може стати оптимальним иляхом досягнення иієї иілі. Посилаючись на иі міркування, ми обрали кілька випадків сочіальної мобільності через систему освіти та вирішили проаналізувати їх за допомогою якісних методів, з метою реконструювати фактори, які вплинули на їх соціальну мобільність, з їх історій життя. Нашу вибірку склали п'ять учнів з кількох віденських середніх шкіл, яким вдалося потрапити до гімназії. Нашою метою було емпірично протестувати певні твердження теорії репродукиії та нової теоретичної перспективи нерепродукиіі. У результаті ідентифіковано певні фактори інституиійного характеру, які ускладнюють освітній шлях школярів $і$ я якими вони мають боротися самостійно, звертаючись до ресурсів сім ї та активуючи власні здібності й якості, шчо Шанталь Жаке називає “комплекцією”. Крім того, нам вдалося окреслити перспективи подальших розвідок: фактори вибору професії, яка може забезпечити висхідну соиіальну мобільність, роль рівня освіти батьків $i$ гендерних особливостей дітей на освітньому шляху.
\end{abstract}

Ключові слова: сочіальна нерівність, репродукція, нерепродукція, сочіальна мобільність, культурний капітал, соціальне походження, “комплекція”, освітній транзит, первинний $i$ вторинний ефект, габітус.

Why do we still talk about inequality in education in modern democratic societies? Education seems to be accessible to everyone. Access to education has increased enormously, but the equal right of participation in the education system does not necessarily lead to a reduction of inequality [1]. This phenomenon has several facets. In the broad sense, equality in education means that the education system offers a right of participation to everyone [2, p. 25, 21-51]. However, it doesn't mean that everyone with the right to participate can profit equally from it. There are many latent factors, which, in a mostly covert way, can block or hinder this access. A child's path through the education system can be strongly influenced by its class of origin, financial situation or the cultural capital of the family. These latent processes also prevent social mobility, which is highly desirable for social development. Frequently it is precisely the educational system itself, that prevents upward social mobility and preserves the existing order and reproduces it instead.

The phenomenon is therefore worth exploring in the context of social inequality, because it is about the distribution of life chances based on educational level. The education system controls access to certain occupations and ways of life based on titles and diplomas [3, p. 43]. In other words, we are talking about the distribution of status and quality of life in society between its members according to their educational success.

The field of research that investigates the co-influence between milieu and education in sense of inequality emerged in the 1970s [4, p. 825]. Bourdieu and Passeron (1977) are among the first authors, who developed theoretical framing of the topic in the "Outline of a Theory of Practice". Further development followed in 1983 with Bourdieu's theory of capital and reproduction and also with the work of Boudon (1974) on the role of decisions in the context of educational inequality. It was increasingly questioned to what extent people's 
practice still had a class or stratum-specific character (Beck, 1986). Furthermore, numerous works in the field of sociology of education were written and empirical studies were conducted. According to the latest state of research, the following studies seem to contribute to the field significantly.

The report of P. Bourdieu on the topic of school and cultural capital can be mentioned as the first one. Of particular interest is the chapter "The Conservative School: The Social Inequality of Opportunity in relation to School and Culture". In this part of his report, P. Bourdieu presented an empirical result of the research in France. This work by Bourdieu on artificial equality of opportunity opens a perspective on the institutional factors that can lead to inequality. He describes the objective mechanisms that cause the presumed exclusion of children from the most disadvantaged classes [5, p. 25]. According to Bourdieu, the main factor of inequality is cultural capital, which influences children's success at school. He claims that the influence of the family milieu is almost exclusively cultural [5, p. 26]. P. Bourdieu has analyzed, based on the quantitative data, the relationship between such factors as the educational level, wealth or place of residence of families and the success and goals of their children. He found that the children of the lower classes are doubly disadvantaged because they have not been able to inherit the natural heritage of cultural capital that the upper classes take for granted. They also lack an ethos of social advancement and striving for success, that are strongly related to the parents' commitment to school $[5$, p. 33]. Bourdieu is convinced that school does not solve this problem and that formal equality is indeed unfair, as it protects privileges of higher class better than opens a transfer opportunity to others [5, p. 39]. In this way, the education system exercises its mystifying function. The philosophy of talent not only offers the elite the opportunity to see themselves justified in their existence, it also makes members of the disadvantaged classes to see their fate as inescapable and convinces them that their social fate is due to their individual nature, their lack of talent [5, p. 46].

M. Jackson in her article "Determined to succeed? Performances versus Choice in Educational Attainment" developed the topic by presenting the results of the study, which was conducted in Denmark, England, France, Germany, Italy, the Netherlands, Sweden and the USA, according to the principle of measuring the primary and secondary effect in the IEO (Inequality of Educational Opportunity) approach. The primary effect refers to school success per se, which should be virtually free from the influence of habitus and only describes the objective abilities of the children that determine success. The secondary effect should come into play during the decision phase and reflect the habitus of the family.

The study by Roth and Siegert, which was carried out in Germany in 2016, examines the transition process from primary school to secondary school. The question that the authors posed in the study is: does the selectivity of the educational system have an impact on minimizing/maximizing educational inequality? For this purpose, they compared the cases where the decision of the teachers was binding and the cases where the parents could decide themselves, in order to find out whether the habitus of the family influences the transition of the child. Based on quantitative results, it was found that regardless of the state and the existence of selectivity procedures, children from higher classes are more likely to attend a Gymnasium than those belonging to socially disadvantaged classes [6, p. 783]. Nevertheless, 
Burak O.S.

the family's habitus determines in different ways the child's further path through the educational system, either by the family's attitude and assistance influencing the child's success (in the case of a binding recommendation) or by the family's more creative and ambitious behavior in the decision-making phase (in the case of a free decision), thanks to its cultural capital.

The study of T. Spiegler is an investigation of the topic "educational success and social background", in which more than 70 scholarship holders, who can be described as the first generation, were interviewed using biographical methods. All of the interviewees were successful students who received a scholarship and whose parents did not have a university degree [7, p. 7]. This result leads one to the question whether the influence of origin and habitus is really quite decisive for the future of the child, or are there perhaps factors that break this law and if so, what are they and how do they work?

The existing studies contribute a lot to the field of study but also reveal some considerable gaps and a lot of new questions for further investigation. The studies often provide an impressive insight into the micro-processes of education. The problem is that the concept of milieu has not yet been linked to the sociostructurally accentuated and established concept of "social milieu" [8, p. 173]. As a result, connections to the macro level cannot be explicitly established, at best only presumed [9, p. 332]. The bottom line is that the possibilities offered by milieu approaches have hardly been exhausted so far. It is noticeable that the school sector has also been little researched to date. Of particular interest would be the studies that take into account the life-world of an individual and institutional dimension of its education story and try to look at transition processes from this perspective [4, p. 842]. In addition, it is essential to explain the "blind spots" in the theory of reproduction, which Chantal Jaquet called non-reproduction: One of them is how can it be explained that children from the disadvantaged classes, despite the deficit of the educational system, do not reproduce their class and manage the upward transit?

The aim of this project was an attempt to understand, using qualitative methods, how the institution of school appears in processes of social mobility and how the negative institutional effects (if identified) could be eliminated on the may of upward social mobility though the educational system.

Theoretical Frame. The most important factor that leads to inequality in education is the capital that the child has at his or her disposal. There are four types of capital: economic capital (income, property); cultural capital (education, knowledge and taste); social capital (social networks - they are at your disposal thanks to birth into a particular family); symbolic capital (prestige) [10, p. 42]. In education, social inequalities were reproduced by the nature of cultural capital. Economic capital is, however, a basic prerequisite for whether a family can afford a certain educational path (including private tutoring costs) at all, although cultural one is more decisive [10, p. 43].

To make this play of capital comprehensible, Bourdieu draws attention to the concept of habitus. Habitus is a way of perceiving, judging, thinking and acting in everyday life. Habitus results from the milieu where a person lives [10, p. 44]. The individual incorporates it unconsciously and reacts to events on its basis, also mostly unconsciously, by using the incorporated patterns $[10$, p. 44]. Habitus makes up the behavior of an individual through 
different kinds of capital, and this then determines one's lifestyle [10, p. 44]. Capital is located in the space around us, which we call milieu.

The "millieutive" nature of education is studied as a part of the sociology of education in order to reconstruct the relation between social inequality and education $[4$, p. 829]. The problem here, however, as P. Bourdieu also asserts in his theory of educational inequalities, is that a child's chance of success at school results much more from its social class than from its personal talents and skills [11, p. 20]. This is precisely the milieu-specific educational style and socialization that the child acquires in the family environment. The cultural heritage that the child inherits, determines its attitude towards educational institutions in general. It is presumed that there is a direct relationship between the general educational level of the family and the success of the child at school. In fact, it is not even the degrees or certificates the parents receive, but much more their general level of education, their social capital [11, p. 26]. The income of the family could be also considered as a factor of influence, but it has been identified that income, with the same level of education, has no influence on school success. On the contrary, the success level of a child varies quite significantly depending on whether the parents have the Abitur (collage certificate) or not $[11$, p. 27].

T. Spiegler's study, which examined more than 70 successful scholarship holders on the subject of educational success, speaks somewhat against this. All of the interviewees were successful students that received a scholarship and whose parents did not have a university degree [7, p. 7]. The thesis that educational success is not directly related to the educational level of the parents can also be confirmed by the fact that the parents of $72 \%$ of students in Italy do not have a higher education certificate [12]. The point here is that a child's failure is likely to be due not only to the educational level of the family, but also to the opportunities that the family is able to provide in general [13]. Even if the family is disadvantaged in sense of income or education level, the parents can be very educationally oriented. They show their interest in the children's education and also invest their time and resources in it. Sometimes it can happen that the parents want to give their children the chance they missed, or they simply want a better life for their children, in particular it is a pattern of behavior of families in the migration situation [14-16].

According to Boudon, there is a primary and a secondary effect that influences educational pathways. The primary effect explains objective school performance of the child. The secondary effect is related to the choices made by parents and children at the transition stages [7, p. 3]. It could be argued that achievement is really an objective factor that has little to do with the origin, although educational decisions are social (subjective) decisions, since they are influenced by the norms and values that are incorporated by the others (so called networks) in the milieu of the students [17, p. 15]. However, is there no influence of origin also on the primary effect? Probably the children do not make enough effort to perform better as they already know that they will not go further. If the children have unconsciously accepted that they are already socially or culturally disadvantaged, they will not make an effort to do the same task as the others as they believe from the very beginning that they will be not able to achieve the same success. It seems pointless to them even to start. They have already accepted their status and show appropriate behavior. According to the study by Roth 
and Siegert, there is a difference between the choices made in the transition from one stage of education to another from higher and lower social classes at the same level of achievement. The children from the disadvantaged classes tend to take an easier route, which is much lower than their real performance. The children from the middle and higher classes (and their families, of course) try all the options to get to a better school, even if their performance is not particularly noticeable. To make the decisions of teachers (based on performance) about the further educational path of the child binding was an attempt to balance the chances so that the leeway of family decisions is minimized. This would reduce to a certain extent the subjectivity of the family's decisions, which depends on its social status.

At this point we would like to draw attention to another point, namely the relationship between performance and its evaluation. Competencies and performance also require corresponding assessment. Teachers decide on the child's potential, but their perceptions are also socially structured and often contribute to the reproduction of social inequality. At these junctures, parental attitudes and teacher assessments can have a greater impact on transition decisions than real competences of the child. Moreover, the current educational system is not ideally suited to accurately measure individual performance. Therefore, the more "transitions" (postponement at school enrolment, repetition of classes, segregated secondary education courses...) there are to be decided, the greater the danger of origin-dependent channeling in the education system $[18$, p. 30].

This raises the question that needs to be addressed at the institutional level: to what extent is the school (as a social institution) responsible for the persistence of social inequality and how could it counteract it?

Firstly, the concept of equality, as has already been mentioned, is questionable. Bourdieu claims that formal equality, the principle on which the education system based, is indeed unjust, and that it better protects privileges in any society committed to democratic ideals [11, p. 39]. School is such an environment where the system recognizes and acknowledges its elite. The culture of the elite is so close to the culture of the school that children from a bourgeois milieu can acquire only with difficulty what is already given to children of the educated classes. In this way, beneficiaries are favored and the most disadvantaged are disadvantaged. In teaching the curriculum, methods and assessment criteria, the school ignores the cultural inequality of the children from the different social classes and in fact sanctions original inequality in relation to culture [11, p. 39]. For example, language (accent, vocabulary, expression) can be informally sanctioned without being explicitly taught or demanded [11, p. 44]. In this way, the school system contributes to the legitimization of inequality [11, p. 45]. By failing to teach, through methodological instruction, to everyone what some owe to their family level, the school sanctions the inequalities that it alone could reduce. An institution whose specific function is to teach and to make one educated person, could compensate for the disadvantages of those who do not find encouragement for cultural practice in their family milieu [11, p. 48]. Because they (culturally disadvantaged) have to expect and receive everything from school [11, p. 41].

Educational institutions have a monopoly position in the distribution of life chances (at the individual level) and in the reproduction of social inequalities (at the societal level) [19, 
p. 695]. The educational success of children depends not only on their behavior, but also to large extent on the opportunities that the school gives them [20]. The point here is that nonequals were treated equally and evaluated according to the same criteria. The problem actually lies in the concept of equality, which seems to have a very positive charge but actually does not lead to a minimization of inequalities, but rather reinforces them even more.

However, one of the critical points of the Bourdieu's theory of reproduction was not to conceive the reproduction as fate or iron law, but to understand social determinisms in order to gain instruments that could work against them. Bourdieu therefore talks about the fine distinctions in the differences. It is precisely this point that Chantal Jaquet has taken up and elaborated the concept of non-reproduction. In doing so, she wanted to point out that there are children who can overcome institutional obstacles. She emphasizes the need to closely investigate the reasons of their exceptional mobility cases [21, p. 14]. It is not easy to answer the questions of individual non-reproduction, since no general theory has been elaborated so far. Nevertheless, Jaquet attempts to reconstruct a set of causes that allows the individual to transform itself and not to fall back into the behavior of its class [21, p. 18]. From this point of view, the exceptional cases can serve as an excellent observatory to determine the decisive factors of an effective change [21, p. 18]. She names this change "transit between classes" and the individuals who make it - "class crossers" [21, p. 20].

Our objective was also to empirically support or disprove the statements that Ch. Jaquet uses in order to develop the theory of non-reproduction by our results that we got from our qualitative empirical analysis of the data from the institute project "Paths into the future" conducted at the University of Vienna.

Empirical implementation. The empirical study "Jugendliche Lebenswelten. Der Weg in/durch das Gymnasium" ("The life worlds of young people. Their ways into/through the Gymnasium"), which was carried out by F. Bisanti, O. Burak and M. Mihailova in 2019 as a part of the project "Wege in die Zukunft" ("Paths into the future") [22] at the Institute for Sociology of the University of Vienna was an attempt to further theorize non-reproduction and to work out a verifiable theoretical model. In this study, the authors dealt with the question: What does help the young people to get into the gymnasium from the middle school and to cope with difficulties there? In doing so, they aimed to find out what exactly could enable an upward social mobility despite the difficulties on the educational path. The sample consisted of five students who ended up in a middle school (NMS) after elementary school but managed to continue their education in a grammar school (Gymnasium) in Vienna, Austria ${ }^{1}$. In order to answer the research question, a secondary data analysis was applied, and the data material was analyzed in a longitudinal section over three years. The

\footnotetext{
${ }^{1}$ The education system in Austria (and also similarly in a range of other European countries) presupposes a separation of students after the first four years of the primary education into two groups according to their success: one group gets a chance to pass to the grammar school (Gymnasium) and later, after graduation, to be able to enter the university with Matura certificate while the other group (less successful students) go to the middle school (NMS) that is more simple and usually doesn't provide graduation with Matura certificate that enables access to the university.
} 
Burak O.S.

data material was provided by the institute project "Wege in die Zukunft" ("Paths into the Future").

About the institute project "Paths into the Future". In the institute project, "Paths into the Future", young people have been accompanied and interviewed for five years beginning from the eighth grade on their way in cooperation with the Vienna City School Board and the New Secondary Schools (NMS). The lives and decisions of young people in the transition phases on their educational phases were seen as appropriate objects for a longitudinal study. The longitudinal analysis was an ideal research method to get a picture of the dynamics in the life of young people that can influence their decisions. The aim was to collect as broad a spectrum of data as possible by combining qualitative and quantitative methods. This would allow to explore both the breadth and depth of young people's experiences. The age of the young people interviewed was between 13 and 16 years at the time of the first wave of the survey.

Study design, case selection and methods of the study "The life worlds of young people. Their ways into/through the gymnasium". The study was a part of the abovementioned project and focused in particular on possible factors that could influence transition decisions and further educational and professional careers of students. It was therefore decided to focus attention on the students who were at that time at different new secondary schools (NMS) in Vienna but have chosen to pass to gymnasium.

The third wave of the institute project involved 22 young persons from the original sample. Therefore, the first criterion was to include into the sample the young people who participated in all three waves, because the aim was to look at their school path on a longitudinal analysis basis. The other criterion was the attendance of a gymnasium at the time of the third wave. Young people who wanted to go to the university chose to pass to gymnasium. All five students in the sample that suited our criteria were female and came from families with a migration background, although this was not the intention of the case selection.

In order to answer the research question, two methods were selected as the most proper for this purpose: topic analysis (Themenanalyse) and fine structure analysis (Feinstrukturanalyse), both according to Lueger (2010). The topic analysis helps to get an overview of the topics and categories when dealing with large amounts of material, and the fine structure analysis helps to reconstruct a latent sense of the text passages that are marked as particularly informative in topic analysis.

The reason of using these methods was the intention to look at the process in depth, not in breadth, as it is usually the case in quantitative studies. These qualitative methods help to reconstruct the latent factors and circumstances through the multidimensional life story of a person.

Results. First, it should be noted that two dimensions in the educational process of young people have opened up: institutional and personal. They can also be mentioned as factors of the macro- and microlevel. The authors have tried to reconstruct the co-influence between them. On the macro level it is the institution school and on the macro level the person with his/her resources. The school appeared to have several factors that are challenging for the students and need to be addressed: unfair grading, discrimination, equal 
treatment of non-equals, language barrier, socially structured treatment of students, lack of individual access and guidance.

"Um, well, there are different subjects and for example in biology, I love biology more than anything, but I got a bad grade and my teacher said you did great on tests, your written assignments are great, but unfortunately you are bad orally, so you don't raise your hand enough to answer. But I'm always present in class, I always take notes, and I get $3(D)$ in my certificate. So that's sad. Because actually I am, in my opinion, good in biology" (case 62, wave 3) [22, p. 40].

"He means uh we are (/) either you understand it at the first time, or you are not suitable for this school. We felt very bad when he said something like that and after my first test, he said m-(/) he meant that I do not belong in this school" (case 108, wave 2) [22, p. 40].

"The teachers said that it wouldn't be good to wear a headscarf at, uh, that age. That's why every time they gave me, how do you say, bad grades or just put pressure on me. And I uh also uh (--) friendship environments I didn't feel well because of just (--) some girls and so on. (--) Then I couldn't stand it anymore, so we changed schools" (case 108, wave 1) [22, p. 41].

The responsibility for overcoming difficulties lies with the person who has to confront such things in education. It depends to a large extent on the resources of the person whether he/she will be successful on the educational pathway or not what is also closely related to his/her origin and social capital. The authors could reconstruct some institutional obstacles, that young people face with on their educational path and the resources that help them to overcome these obstacles.

The results cannot be fully presented in the context of this article, but the categories that apparently overlap with the theory of Chantal Jaquet have been reconstructed and a few conclusions that contribute to the discussion of Bourdieu's approach have been drawn.

“Complexion" and ambition as its significant component. Chantal Jaquet introduces the concept of complexion in her book. Complexion is a bundle of physical, mental and psychological determinations [21, p. 100]. According to Jaquet, they are mostly not innate but acquired abilities. For example, ambition, which she sees as the engine of nonreproduction and social advancement, sweeps away all fears [21, p. 33]. Jaquet claims that ambition has nothing to do with the ideology of giftedness and is not a first cause but a cognitive determination [21, p. 36]. This idea is also confirmed by the analysis in this study.

"Maja \#\# has only one (A) in her certificate and //mhm//I I don't have something like that and that's why I would, I learn so often (...)” (case 52, wave 1) [22, p. 25].

Here, ambition is closely related to the goal.

"But, well, I like it anyway. Because, somehow you get more of this 'I have to do better now' and everything depends on you, how you are like, whether you go on or think 'yes, whatever', but I'm one of those who goes on and wants to reach the goal" (case 62, wave 2) $[22$, p. 38].

The respondents strive for social recognition here and now, because they do not feel fully integrated and want to get ahead at all costs, be it learning the language, making friends or improving performance in order to gain authority in the friend circle. 
"Um (-) um I really wanted tutoring $o$ - (/) I really wanted to take the Ü-class (/) I didn't want to go to the fifth grade when I am sixteen/seventeen first, that would be a bit (//) there are still four years ahead of me to get my Matura, that then (I/) It's not bad if you repeat, but I really wanted to go into the fifth grade" (case 106, wave 3) [22, p. 36].

In the long run it is social recognition due to the prestigious profession. So, the efforts to get into the grammar school (gymnasium) and to stay there are to be explained by the wish to reach social recognition and high social status that also mean independence and financial security. This leitmotif runs through all 5 cases and can be clearly identified as one of the main factors.

Mimesis. Mimesis is a model that the individual wishes to be like [21, p. 34]. It can be two-dimensional:

- The family model: existence of a relative who has studied and achieved a good social placement. This was a strong motivation factor in 4 out of 5 cases (they were elder brothers/sisters or cousins):

"My sister told me to go, because when you go to an upper school, you have more goals, because there (/) you have general knowledge and //hmhm/// with Matura (/) you say, with Matura you can earn more or something. My sister goes to the upper school... And I have a lot more in mind (/) I can achieve a lot with the Matura" (case 108, wave 1) [22, p. 44];

- The school model: a devotion and a missionary spirit of some teachers who are imbued with the feeling of their pedagogical as well as social duty, especially towards intelligent students [21, p. 50]:

"...Yeah, so I asked my teachers what the best school was, like, nearby. And then they said, yes, Polgar isn't bad, because AHS is high school, is high school, and uh, you could easily manage, even if you (//) And they told me right away, um, it's just that you can't have exactly the same grades in high school, from middle school to AHS. A's and a B, for example. You'll probably get two grades worse, but that will change, because it's a matter of getting used to it" (case 62, wave 2) [22, p. 41].

This was the moving factor in the fifth case, where the recommendations and encouragement of the teacher put the student on the path of the gymnasium and helped her to overcome the initial difficulties of adaptation.

Affects. Affects are physical and mental modifications that explain what touches, moves and excites us [21, p. 67]. Like any culture shock, the friendly or amorous encounters between people from different classes or cultures goes hand in hand with a redesign of identity by opening up to an otherness that one wants to make one's own and to archive integration [21, p. 69]. With the help of affect, the process of adaptation becomes less painful and faster, as the person finds it positive to become similar to a friend and enjoys the progress. In the study it was also identified that the students had language difficulties which led to failure, exclusion and even bullying:

“(...) Because I could not speak German and there the children were already too good, so, I had to go into the first grade and it was even worse in the first, I was always bullied because I did not know German (...)" (case 106, wave 1) [22, p. 25].

They could overcome them by the friendships that helped a lot in learning German: 
“(...) There was a boy who spoke Russian //mhm/I/ and always translated everything for me, that's why I managed to learn the language so quickly and learned it well (...)" (case 62, wave 1) [22, p. 23].

Whether it was a friend who had the same mother tongue or common work on the material with classmates:

“Because, I wanted to have only A's, so I studiedwith@Dana\#\#,because she got an $A$ and I got a B. And I wanted to get an A at some point" (case 71, wave 1) [22, p. 34];

"...And I always ask her, what are your study tips and I try to take her as a model for (/) school. And she says like, oh, that's sweet, and yes, you have to do this and that and not let it get you down" (case 62, wave 2) [22, p. 34].

It was possible to reach the goal faster in the form of learning groups through shared effort. A network of friends supports learning process and contributes to better grades. Especially for students from low-income families, such "learning groups" can replace costintensive tutoring. The power of friendship breaks down social and institutional barriers.

Selection of the school and free choice of the family. Such factor as selection process at the school does not justify the initiative to reduce educational inequalities as it results from the subjective teacher's decisions. As it has already been theoretically tested, the perception and, as a consequence, the assessment of the teacher is also socially structured and often tends to reinforce inequalities:

"I could actually go to an AHS, I/hm// but the teacher, I don't think she liked me, she didn't want to give a good grade. Instead of a threesome, she wrote a four on my certificate and that's why I couldn't go to AHS, but here and (-) yes. That is why I came here" (case 108, wave 1) [22, p. 28].

All cases in the study are a great example of the fact that the transition was an initiative of the family or the pupil have found such a way out on their own:

“...Yes, yes. When@@ @ Anes\#\# was still going to school there, so she kept telling me what it was like at school. And through all this information I finally decided to go there" (case 62, wave 2) [22, p. 45].

...And that the institution of school was wrong in this respect, as it could not recognize the potential of the students and could not steer them to move upwards educational path. In one out of 5 cases, school became even a hindrance that the family had to overcome through cohesion and mutual support. The lack of self-confidence that the pupil has acquired in the elementary school through the experiences of discrimination has led to her apathetically bowing to her fate because she does not believe in herself:

"...And (--) my degree has dropped so low, so my grades so //mhm/// I (-) then the idea occurred to me to quit school, but fortunately my courage-(/) my parents motivated me and so that I can make it. They have me (/) they also support me and say that I can always improve myself" (case 108, wave 2) [22, p. 29].

Educational level and parents' attitude towards school. Two perspectives were described in the theoretical part of the article. From Bourdieu's point of view, the parents' degree plays a decisive role in the child's success. In Spiegler's study, it was proven that $70 \%$ of the scholarship holders were the children of parents who did not have a higher degree. Our 
Burak O.S.

study can neither commonly agree with, nor distract from the two perspectives. It seems that the level of education does play a curtain role, since there were two cases where one or both of the parents had a higher degree, the rest had at least Matura (high school certificate) except one case. But in this curtain case the student faced more problems on her school path than others, which could also be an indication that the level of education does play a role. However, this topic should be explicitly investigated in further studies.

Another point, however, as has been explained theoretically, is that not only certificates, but also general education level of the family is of great importance, as well as their attitude towards education in general. The positive attitude of the parents towards education, their motivation and efforts to give the children the better future could be identified in all cases of the study:

"My mother just says you're doing it for you, like everything. And no matter what you take, I'll always support you” (case 62, wave 2) [22, p. 44].

In our case, where quite by chance all the respondents had a migrant background, it is also to be stated that, as it was mentioned in the theoretical framework, the parents have tried to create the opportunity, which they probably missed themselves, for their children and invest their time and resources in it. This could also be a reaction resulting from their migration experience. The families have sacrificed a lot and do not want the whole thing to be in vain. Furthermore, the migration situation is also about social recognition, which is most certainly possible through a good job. In any case, the role of the migration experience in this context should be explored more closely.

The opportunities of the family. It was emphasized in the theoretical part of the article that not necessarily the parents' degree of education plays a decisive role, but also other possibilities that the family can offer. It occurred so also in the data analysis. If the parents are always willing to invest in the child's education in all senses (their time, advices, motivation talks, help with home tasks and etc.), if they can provide them with a suitable household, their own room, pocket money so that they feel comfortable and safe and stay concentrated at school, the children will perform better:

"I took a course because of this Cambridge test, then I also took my business license, ...I just wanted to do something, so just because. (...) I did (/) so that if you do more courses, it means that it's a better certificate and I actually only did it so that I know more" (case 52, wave 2) [22, p. 38].

All young people from the study who could pass to the gymnasium made it due to more or less secure economic situation of the family. An extremely motivated and ambitious young girl, in addition to her school activities, pursues various hobbies which help to strengthen her self-confidence and integrate her into various social networks. Another girl was also able to improve her grades and learn a musical instrument with the financial support of her parents.

Summary. To sum up, we can state that there is a certain number of institutional factors that make it difficult for young people to get to and through gymnasium, and with which they must deal on their own. The school itself often creates inflexible institutional frameworks for young people who struggle to adapt in order to reach their goals. High performance demands, unfair grading, time stress, fear of negative grades, all of these factors 
affect the motivation to learn. Thus, these difficulties have a structural character and should be eliminated by processing social structures.

In this situation, the adolescents had to use their own available resources such as family support, the circle of friends, their own strength, etc. to cope with this challenge. Their ambitions to gain an acceptance and recognition, to be as successful as possible in order to reach the social status they aimed was the main factor that brought them to the grammar school. This factor was also noted by Chantal Jaquet as one of the most important components of the process of non-reproduction.

The notion of the mimesis was also proved by the analysis. There was a model that could light the path of students in every of studied cases: family model (e.g. elder sister) or school model (e.g. teacher).

The influence of affects was also to identify friendship with the students, who was already in the "chamber of success".

Besides, we can disprove, so far, the idea that the family is mostly going to reproduce its social class through the unambitious decisions on the educational path. We could observe that it was a family effort to give a child a better education opportunity in all cases.

Also, we can claim that the financial opportunities of the family make a significant contribution to the educational success of the students.

Although we would like to note, that the results of the study could not still be applied to the whole population as the range of the studied cases was not wide enough.

Further Research Perspectives. All five students in the sample were female and came from families with a migration background, where patriarchal social norms predominate. Although this was not the intention of the case selection, we believe that at this point it makes sense to explore the double socialization of women. The compatibility of family and career is an important aspect in the career and educational choices of young women:

"I wanted it so - to go to university. I want it still, but if it takes too long... You think it's going to take so long, and only when you're grown up. Everything can change before then, you never know if you will get into a relationship and what will happen and, uh" (case 106, wave 2) [22, p. 37].

The compulsion to deal with this aspect sometimes does not come in favor of educational motivation. In any case, it would not be uninteresting to look at the process of education with gender-specific glasses.

The role of the educational level of the parents remains questionable and could be further researched.

Furthermore, an interesting perspective on the career choice of social climbers opens up: all 5 girls have chosen medicine as their future profession:

"Mhh I would like to study. Would be nice if it is medicine (laughs) //mhm//. I would (/) I already have (/) so I've already made some plans, maybe I should study English first //mhm// so I wouldn't do medicine right away, because that would be really exhausting and maybe I should do English first and then study medicine it would be nice so um like oncology //mhm// would be really nice (-) yes //mhm// I've already thought about that (laughs) //ok mhm// medicine. If not, then it will be something else, but //ok/// at the moment it would be nice if it 
Burak O.S.

was medicine //if it is medicine // yes //ok// which is still difficult but you know" (case 52, wave 3) [22, p. 36].

It would be interesting to see what contributes to the choice of profession and what criteria the young people focus on.

Migration background is another topic that deserves a closer look. Social contacts and communication play a special role for young people with migration background. Peer groups and friendships are important for the identity formation of young people, their social integration and as a consequence for their school success.

\section{References}

1. Chien, C.-L., Montjouridès, P., Van der Pol, H. (2017). Global trends of access to and equity in postsecondary education. In Access to higher education: theoretical perspectives and contemporary challenges (pp. 3-32). Abingdon, Oxon, New York, NY: Routledge.

2. Equity in Education. Breaking down barriers to social mobility. (2018). OECD. Overview and policy implications. Paris: OECD Publishing. https://doi.org/10.1787/9789264073234-en

3. El-Mafaalani, A. (2012). BildungsaufsteigerInnen aus benachteiligten Milieus. Wiesbaden: Springer VS. https://doi.org/10.1007/978-3-531-19320-5 [in German]

4. Bremer, H. (2012). Die Milieubezogenheit von Bildung. In Handbuch Bildungssoziologie (pp. 829846). Wiesbaden: Springer VS. https://doi.org/10.1007/978-3-531-18944-4_49 [in German]

5. Bourdieu, P. (2001). Die Konservative Schule. In Wie die Kultur zum Bauern kommt. Über Bildung, Klassen und Erziehung (pp. 25-52). Hamburg: VSA [in German]

6. Roth, T., Siegert, M. (2016). Does the Selectivity of an Educational System Affect Social Inequality in Educational Attainment? Empirical Findings for the Transition from Primary to Secondary Level in Germany. European Sociological Review, 32 (6), 779-791. https://doi.org/10.1093/esr/jcw034

7. Spiegler, T. (2018). Resources and requirements of educational upward mobility. British Journal of Sociology of Education, 13, 6. https://www.tandfonline.com/doi/full/10.1080/01425692.2018.1425131 ?scroll=top\&needAccess=true https://doi.org/10.1080/01425692.2018.1425131

8. Bohnsack, R., Nentwig-Gesemann, I., Nohl, A.-M. (2007). (Hrsg.): Die dokumentarische Methode und ihre Forschungspraxis. Opladen: VS. https://doi.org/10.1007/978-3-531-90741-3

9. Kramer, R.-T. (2011). Abschied von Bourdieu? Perspektiven ungleichheitsbezogener Bildungsforschung. Wiesbaden: VS Verlag für Sozialwissenschaften [in German]

10. Erler, I. (2007). Die Illusion der Chancengleichheit. In Keine Chance für Lisa Simpson? Soziale Ungleichheit im Bildungssystem (pp. 39-47). Wien: Mandelbaum Verlag [in German]

11. Bourdieu, P., Passeron, J.-C. (1977). Reproduction in Education, Society and Culture. London: Sage.

12. Hauschild, K., Gwosć, C., Netz, N., Mishra, S. (2015). Social and Economic Conditions of Student Life in Europe. Synopsis of indicators. Eurostudent V 2012-2015. Bielefeld: W. Bertelsmann Verlag [in German]

13. Gofen, A. (2009). Family Capital: How First-Generation Higher Education Students Break the Intergenerational Cycle. Family Relations, 58 (1), 104-120. https://doi.org/10.1111/j.17413729.2008.00538.x

14. King, V. (2006). Ungleiche Karrieren. Bildungsaufstieg und Adoleszenzverläufe bei jungen Männern und Frauen aus Migrantenfamilien. In V. King, H.-Ch. Koller (Eds.), Adoleszenz - Migration - Bildung. Bildungsprozesse Jugendlicher und Erwachsener mit Migrationshintergrund (pp. 27-46). Wiesbaden: VS Verlag für Sozialwissenschaften. https://doi.org/10.1007/978-3-531-90332-3_2 [in German]

15. London, H.B. (1989). Breaking Away: A Study of First-Generation College Students and Their Families. American Journal of Education, 97 (2), 144-170. https://doi.org/10.1086/443919 
16. Raiser, U. (2007). Erfolgreiche Migranten im deutschen Bildungssystem - es gibt sie doch. Berlin: LIT Verlag. Books.

17. Jackson, B., Marsden, D. (1966). Education and the Working Class. Harmondsworth: Penguin

18. Solga, H. (2005). Meritokratie - die moderne Legitimation ungleicher Bildungschancen. In Institutionalisierte Ungleichheiten. Wie das Bildungssystem Chancen blockiert (pp. 19-38). Weinheim/München: Juventa Verlag [in German]

19. Bell, D. (1994). The Coming of Post-Industrial Society. In Social Stratification: Class, Race, and Gender in Sociological Perspective (pp. 686-697). Boulder, CO: Westview Press.

20. Gomolla, M., Radtke, F.-O. (2002). Institutionelle Diskriminierung. Die Herstellung ethnischer Differenz in der Schule. Opladen: Leske + Budrich [in German]

21. Jaquet, Ch. (2018). Zwischen den Klassen: Über die Nicht-Reproduktion sozialer Macht. Göttingen: Konstanz University Press [in German]

22. Bisanti, F., Burak, O., Mihailova, M. (2019). Jugendliche Lebenswelten. Der Weg in/durch das Gymnasium. Wien [in German]

Received on 9.04.20 and updated on 30.04.20 